\title{
Exposure to Supplemental Oxygen and Its Effects on Oxidative Stress and Antioxidant Enzyme Activity in Term Newborn Lambs
}

\author{
VASANTH H. KUMAR, ANUPAMA PATEL, DANIEL D. SWARTZ, HUAMEI WANG, KAREN A. WYNN, LORI C. NIELSEN, \\ AND RITA M. RYAN
}

Department of Pediatrics, University at Buffalo, Buffalo, New York 14214

\begin{abstract}
The optimal oxygen concentration for the resuscitation of term infants remains controversial. We studied the effects of 21 versus $100 \%$ oxygen immediately after birth, and also exposure for $24 \mathrm{~h}$ to $100 \%$ oxygen, on oxidant lung injury and lung antioxidant enzyme (AOE) activities in term newborn lambs. Lambs at $139 \mathrm{~d}$ gestation were delivered and ventilated with $21 \%$ (RAR) or $100 \%$ (OXR) for $30 \mathrm{~min}$. A third group of newborn lambs were ventilated with $100 \% \mathrm{O}_{2}$ for $24 \mathrm{~h}$ (OX24). Oxidized glutathione levels in whole blood were significantly different among the groups with lower values in the RAR group, and these values correlated highly with partial pressure of arterial oxygen $\left(\mathrm{PaO}_{2}\right)$. The reduced to oxidized glutathione ratio was significantly different among the groups, the ratio decreasing with increasing oxygen exposure. Lipid hydroperoxide (LPO) activity was significantly higher in the OXR and OX24 groups. AOE activity was higher in the whole lung and in red cell lysate in the OX24 group. Increased myeloperoxidase (MPO) activity, percent neutrophils, and proteins in lung lavage suggested inflammation in the OX24 group after maximal oxygen exposure. We conclude that even relatively brief exposure of the lung to $100 \%$ oxygen increases systemic oxidative stress and lung oxidant injury in ventilated term newborn lambs. (Pediatr Res 67: 66-71, 2010)
\end{abstract}

$\mathrm{T}$ he fetal lung is exposed to an abrupt increase in ambient oxygen tension at the time of birth. This results in oxidative stress in infants soon after birth $(1,2)$. Factors such as free radical generation from oxygen exposure, inflammation, and lower antioxidant stores may result in exaggeration of this oxidative stress response. Experimental resuscitation with $100 \%$ oxygen compared with room air has been associated with the generation of oxygen radicals (3). Although there are no data on the danger of short-term exposure to $100 \%$ oxygen, studies of reperfusion after hypoperfusion states suggest that this is precisely the time when oxygen toxicity from free radicals is likely to occur (4). Although, traditionally, neonatal resuscitation has been performed with $100 \%$ oxygen, current evidence is insufficient to resolve all questions regarding supplemental oxygen use in neonatal resuscitation (5). Studies in asphyxiated term infants have shown that $100 \%$ oxygen resulted in hyperoxemia and significantly higher oxidative

Received February 27, 2009; accepted August 26, 2009.

Correspondence: Vasanth H. Kumar, M.D., Department of Pediatrics, University at Buffalo, The Women \& Children's Hospital of Buffalo, 219 Bryant Street, Buffalo, NY 14222-2006; e-mail: vkumar@upa.chob.edu

Supported by a grant from the American Academy Pediatrics/Neonatal Resuscitation Program 1040244 [V.H.K.]. stress compared with room air resuscitation (RAR) offering no additional benefit to these infants at least in the short term (6).

We have shown previously that in term newborn lambs, the use of $100 \%$ oxygen for the first $30 \mathrm{~min}$ after birth during the typical resuscitation period results in an increased contractility response in pulmonary arteries isolated at $24 \mathrm{~h}$ of age (7). We have also shown that ventilation with $21 \% \mathrm{O}_{2}$ results in a rapid reduction in pulmonary vascular resistance and does not interfere with subsequent vasodilation to $\mathrm{NO}$ and acetylcholine, whereas resuscitation with $100 \% \mathrm{O}_{2}$ impairs vasodilation to these agents (8). Because oxidative stress influences apoptosis and cell growth (9), oxygen exposure may have long-term consequences on growth and development. The effect of varying concentrations of supplemental oxygen in a hyperoxic nonasphyxiated model on oxidant stress, inflammation, and antioxidant enzymes (AOE) is not clear.

We hypothesized that exposure to room air rather than $100 \%$ oxygen soon after birth for 30 min would decrease systemic and lung oxidant stress and longer exposure to supplemental oxygen $(24 \mathrm{~h})$ would worsen oxidant lung injury and lung inflammation in ventilated newborn lambs. Lambs resuscitated with $100 \%$ oxygen had systemic oxidative stress and free radical damage comparable to the room air group, and exposure to supplemental oxygen for $24 \mathrm{~h}$ (OX24) resulted in significant oxidant stress, inflammation, and up-regulation of AOE activity in the lung.

\section{METHODS}

We compared the effects of 30 min of $100 \%$ oxygen versus $21 \%$ oxygen followed by ventilation for a total of $24 \mathrm{~h}$ in term newborn lambs targeting partial pressure of arterial oxygen $\left(\mathrm{PaO}_{2}\right)$ levels of 45 to $65 \mathrm{~mm} \mathrm{Hg}$, and, in a third group, exposure to $100 \%$ for $24 \mathrm{~h}$. The study was approved by the Institutional Animal Care and Use Committee (IACUC) of the University at Buffalo.

Near-term gestation pregnant ewes at $139 \mathrm{~d}$ gestation (term $=145 \mathrm{~d}$ ) were brought to the lab animal facility $72 \mathrm{~h}$ before the surgery. After $12 \mathrm{~h}$ of fasting, the ewe was intubated and ventilated under Pentothal and Halothane. Lambs were exteriorized by cesarean section. Systemic arterial and venous access was established through the carotid artery and jugular vein, respectively. The lambs were intubated, delivered, and placed on a servo-controlled radiant warmer. Rectal temperature was maintained between 38.0 and $39.0^{\circ} \mathrm{C}$. All

\footnotetext{
Abbreviations: AOE, antioxidant enzyme; GSH, reduced glutathione; GSSG, oxidized glutathione; GP, glutathione peroxidase; LPO, lipid hydroperoxides; MPO, myeloperoxidase; SOD, superoxide dismutase
} 
lambs were ventilated with Servo 300 ventilators (Seimens, Mississauga, ON, Canada) at a rate of 60 breaths/min, positive end expiratory pressure of 4 and peak inspiratory pressure (PIP) of approximately $25 \mathrm{cms}$ of $\mathrm{H}_{2} \mathrm{O}$ (adjusted to deliver $10 \mathrm{~mL} / \mathrm{kg}$ tidal volume using a Bicore CP-100 Monitor, Bicore Monitoring systems, Irvine, CA) (10). Lambs were sedated soon after birth with Buprenorphine $0.01 \mathrm{mg} / \mathrm{kg}$ IV followed by Fentanyl $2 \mu \mathrm{g} / \mathrm{kg}$ IVq2h PRN. Lambs received a single dose of pancuronium $0.1 \mathrm{mg} / \mathrm{kg} / \mathrm{dose}$ at birth, which was repeated only if necessary for vigorous spontaneous movement despite adequate narcotic sedation (required for two lambs in each group). I.V. fluids (dextrose 10\%; $\mathrm{NaCl}: 25 \mathrm{mEq} / \mathrm{L} ; \mathrm{KCl}: 20 \mathrm{mEq} / \mathrm{L} ; \mathrm{NaHCO}_{3}: 10$ $\mathrm{mEq} / \mathrm{L}$ ) were administered continuously at $100 \mathrm{~mL} / \mathrm{kg} / \mathrm{d}$. Arterial blood gases were done every $5 \mathrm{~min}$ for the first $30 \mathrm{~min}$, every $15 \mathrm{~min}$ for the next $30 \mathrm{~min}$ and then hourly until sacrifice at $24 \mathrm{~h}$. Ventilator settings were adjusted to maintain partial pressure of arterial carbon dioxide $\left(\mathrm{PaCO}_{2}\right)$ between 35 and $50 \mathrm{~mm} \mathrm{Hg}$. Any change in ventilation parameters was followed by a blood gas within $30 \mathrm{~min}$.

The lambs were assigned randomly to one of three groups before delivery: 1) Lambs ventilated in $21 \%$ oxygen for 30 min ("Room Air Resuscitated," or the RAR group); 2)Lambs ventilated initially in $100 \%$ oxygen for $30 \mathrm{~min}$ ("Oxygen Resuscitated," or the OXR group); 3) Lambs ventilated in 100\% for $24 \mathrm{~h}$ (OX24). In the RAR and OXR groups, $\mathrm{FiO}_{2}$ was adjusted after $30 \mathrm{~min}$ to maintain $\mathrm{PaO}_{2}$ between 45 and $65 \mathrm{~mm} \mathrm{Hg}$. The $\mathrm{FiO}_{2}$ weaning protocol for the OXR group is described elsewhere (7). PIP was adjusted to maintain $\mathrm{PaCO}_{2}$ of 35 to $50 \mathrm{~mm} \mathrm{Hg}$ and $\mathrm{pH}$ of 7.35 to 7.45 . PIP was weaned aggressively to avoid overdistension of the lung based on chest movement and $\mathrm{PaCO}_{2}$.

Hypotension (mean blood pressure $<35 \mathrm{~mm} \mathrm{Hg}$ ) was treated with normal saline and sodium bicarbonate was administered for a base excess $>-8$ $\mathrm{mEq} / \mathrm{L}$. Blood was collected at prebirth, $30 \mathrm{~min}, 4 \mathrm{~h}$, and $24 \mathrm{~h}$ after birth for measurement of reduced glutathione (GSH) and oxidized glutathione (GSSG). Lambs were killed at $24 \mathrm{~h}$ of life with $100 \mathrm{mg} / \mathrm{kg}$ i.v. Nembutal and heart and lungs were removed enbloc at peak inspiration. Lung tissue was perfused with heparinized PBS. Perfused lung tissue was weighed, homogenized in assay buffer, centrifuged, and the supernatant was stored at $-80^{\circ} \mathrm{C}$. Pulmonary edema was assessed by wet to dry weight ratio of the lung. A piece of right lung (always the cardiac lobe) was cleaned, weighed, and then air-dried for 2 wk. The lung was reweighed for estimation of dry weight. Right upper lobe was lavaged with $50 \mathrm{~mL}$ of Ringer's lactate, centrifuged at $850 \mathrm{rpm}$ for 11 min to separate the supernatant and the cell pellet. The cell pellet was resuspended in PBS and an aliquot was used for total and differential count. Total cell count was determined using a standard Neubauer hemocytometer. Differential count was performed by counting cells on cytospin preparations of resuspended cell pellet stained with Diff-Quik kit (Fisher Scientific, Pittsburgh, PA). Total protein in the lung and in the lavage was quantified by the Lowry method (11).

Measurement of GSH and GSSG. GSH and GSSG samples were shipped on dry ice to Oxis Research for measurement of GSH/GSSG ratio using a Bioxytech GSH/GSSG-412 assay kit (Oxis Research Assay Service, Portland, OR). GSSG samples were prepared by adding $10 \mu \mathrm{L}$ M2VP (1-methyl-2vinylpyridium trifluoromethanesulfonate, a thiol scavenger) to $100 \mu \mathrm{L}$ of whole blood. Complete scavenging of GSH was accompanied in less than a minute by M2VP. Total GSH $\left(\mathrm{GSH}_{\mathrm{t}}\right)$ was measured in $50 \mu \mathrm{L}$ of whole blood. The method uses Ellman's reagent, which reacts with GSH to form a spectrophotometrically detectable product at $412 \mathrm{~nm}$. GSSG was determined by reduction of GSSG to GSH, which is then determined by the reaction with Ellman's reagent. Reduced GSH is the difference between GSH $_{\mathrm{t}}$ and GSSG.

Lipid hydroperoxide and myeloperoxidase measurements. Perfused lung tissue was homogenized in $10 \mathrm{~mL}$ of $4-\mathrm{mM}$ butylated hydroxytoluene and 10 -mM PBS per gram tissue. The samples were centrifuged at $10,000 \times \mathrm{g}$ for $15 \mathrm{~min}$. The resultant supernatant was then analyzed using a direct colorimetric measurement kit for lipid hydroperoxides (LPOs) (Bioxytech LPO560). For measurement of myeloperoxidase (MPO) activity lung tissue and lavage cell pellet were homogenized in MPO buffer and centrifuged at $40,000 \times \mathrm{g}$ for $25 \mathrm{~min}$. MPO was measured in the supernatant using a spectrophotometric reaction with $o$-dianisidine hydrochloride as a substrate. The reaction was stopped with $1 \%$ sodium azide and the absorbance read at $450 \mathrm{~nm}$ in a spectrophotometer. The results were obtained with Softmax-Pro 4.3. MPO activity was expressed as units/mg protein.

AOE activities in the lung and red blood cell lysate. Lung tissue was homogenized in $10 \mathrm{~mL}$ of superoxide dismutase (SOD) buffer (cold $20 \mathrm{mM}$ HEPES buffer, containing $1 \mathrm{mM}$ EDTA, $210 \mathrm{mM}$ mannitol, and $70 \mathrm{mM}$ sucrose) per gram tissue, centrifuged at $1500 \times \mathrm{g}$ for $5 \mathrm{~min}$, and the resultant supernatant was assayed for SOD activity using a commercially available kit (Catalog No. 706002, Cayman Chemicals, Ann Arbor, MI). The SOD assay measured total SOD activity. For the catalase assay, the tissue was homogenized in $10 \mathrm{~mL}$ of $50 \mathrm{mM}$ potassium phosphate, containing $1 \mathrm{mM}$ EDTA per gram tissue. The homogenized tissue was centrifuged at $10,000 \times \mathrm{g}$ for 15 min. The supernatant was assayed for catalase activity using an assay kit (Catalog No.707002, Cayman Chemicals, Ann Arbor, MI). For glutathione peroxidase (GP) activity, the tissue was homogenized in $10 \mathrm{~mL}$ buffer containing $50 \mathrm{mM}$ Tris- $\mathrm{HCl}, 5 \mathrm{mM}$ EDTA, and $1 \mathrm{mM}$ DTT per gram tissue and then centrifuged at $10,000 \times \mathrm{g}$ for $15 \mathrm{~min}$. The resultant supernatant was then assayed for GP activity using a commercially available kit (Catalog No.703102, Cayman Chemicals, Ann Arbor, MI). For measurement of red cell AOE activities, whole blood was collected in heparinized tubes at prebirth and at $24 \mathrm{~h}$. The tubes were centrifuged at $1000 \times \mathrm{g}$ for $10 \mathrm{~min}$ and red cells were pipetted into Beckman centrifuge tubes. Then, they were diluted with four volumes of water and allowed to stand on ice for $10 \mathrm{~min}$ for lysis to occur. The tubes were then centrifuged at $10,000 \times \mathrm{g}$ for $15 \mathrm{~min}$. The supernatant was then assayed for AOE activities as described above.

All data are expressed as mean \pm SEM, with $n$ representing the number of animals studied ( $n=5$ in each group). Statistical analysis was done using ANOVA and linear regression analysis. Fisher's posthoc test was used to compare groups. Mixed modeling was used to study the effects of groups and time on GSH, GSSG, and GSH/GSSG ratio. A $p$ value of $<0.05$ was considered significant.

\section{RESULTS}

Oxygen exposure and arterial oxygenation. As designed, the $\mathrm{FiO}_{2}$ was initially disparate, but then there was no difference in $\mathrm{FiO}_{2}$ between RAR and OXR groups after the first $2 \mathrm{~h}$ of life (Fig. 1). Lambs in both the RAR and OXR groups required 25 to $30 \%$ oxygen to maintain $\mathrm{PaO}_{2}$ of 45 to $65 \mathrm{~mm}$ $\mathrm{Hg}$ for the duration of the study. The arterial $\mathrm{Po}_{2}$ in the first 30 min in the OXR group varied between 259 ( \pm 48 ) and 334 ( \pm 70 ) $\mathrm{mmHg}$ (Fig. 2). $\mathrm{PaO}_{2}$ in the RAR group in the same 30 -min period was between $35( \pm 11)$ and $50( \pm 12) \mathrm{mmHg}$ (Fig. 2). There was no significant difference in $\mathrm{PaO}_{2}$ between OXR and RAR groups after the first $2 \mathrm{~h}$ of life. As designed, the $\mathrm{PaO}_{2}$ in the OX24 group was between 327 ( \pm 31 ) and 472 $( \pm 55) \mathrm{mmHg}$ for the duration of the study. There was no difference in the mean airway pressure at the beginning (30 min) and at the end of the study ( $24 \mathrm{~h}$ ) among the three groups (Table 1). There was no significant difference in $\mathrm{PaO}_{2}, \mathrm{PaCO}_{2}$, and $\mathrm{pH}$ values between RAR and OXR groups in the first 30 min of life. Despite differences in initial $\mathrm{FiO}_{2}$, no differences were noted in $\mathrm{pH}$, base deficit, or $\mathrm{PaCO}_{2}$ between the two resuscitation groups over the 24 -h period (Table 1).

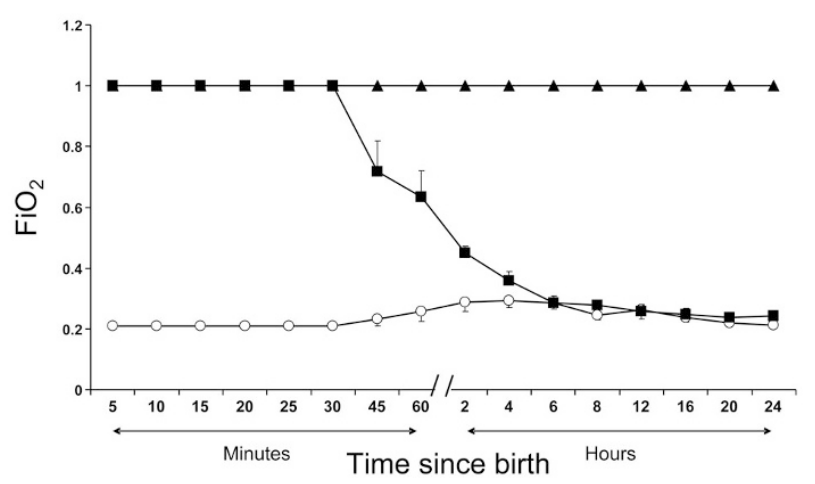

Figure 1. Three groups of lambs based on oxygen exposure are shown with $\mathrm{FiO}_{2}$ along the $y$ axis and time since birth along $x$ axis. Term lambs were ventilated with $21 \%$ oxygen (RAR-open circles); or in $100 \%$ oxygen (OXR—closed squares) for the first $30 \mathrm{~min}$ of life. Subsequently, oxygen was adjusted to maintain $\mathrm{PaO}_{2}$ of 45 to $65 \mathrm{~mm} \mathrm{Hg}$ for $24 \mathrm{~h}$ in both the groups. Lambs ventilated with $100 \%$ for $24 \mathrm{~h}$ (OX24-closed triangles) were studied for comparison ( $n=5$ in each group; values represent mean \pm SEM). There was no significant difference in $\mathrm{FiO}_{2}$ between the RAR and OXR groups after the first $2 \mathrm{~h}$ of life. 


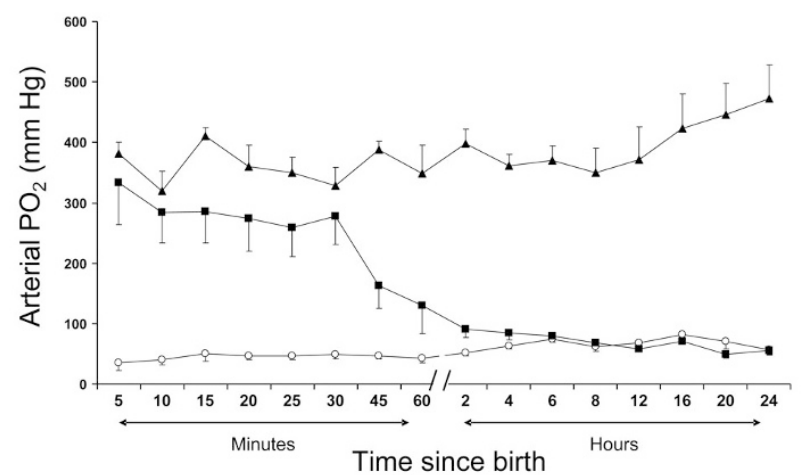

Figure 2. Arterial $\mathrm{Po}_{2}$ in the three groups of lambs studied are shown with $\mathrm{PaO}_{2}$ along $y$ axis and time since birth along $x$ axis (RAR-open circles; OXR-closed squares; OX24-closed triangles). $\mathrm{PaO}_{2}$ after $21 \%$ (RAR) or $100 \%$ (OXR) ventilation in the first $30 \mathrm{~min}$ is shown in detail. There was no significant difference in $\mathrm{PaO}_{2}$ between RAR and OXR groups after the first $2 \mathrm{~h}$ of life. OX24 group had a higher arterial $\mathrm{Po}_{2}$ by design (values represent mean \pm SEM).

Table 1. Baseline characteristics, ventilation and arterial blood gas parameters of lambs resuscitated in $21 \%$ oxygen (RAR), $100 \%$ oxygen (OXR) and ventilated in $100 \%$ for $24 \mathrm{~h}$ (OX24)

\begin{tabular}{lccc}
\hline \multicolumn{1}{c}{ Characteristic } & $\begin{array}{c}\text { RAR group } \\
(N=5)\end{array}$ & $\begin{array}{c}\text { OXR group } \\
(N=5)\end{array}$ & $\begin{array}{c}\text { OX24 group } \\
(N=5)\end{array}$ \\
\hline Birth weight $(\mathrm{gms})$ & $3,445 \pm 304$ & $3,285 \pm 396$ & $3,004 \pm 241$ \\
$\mathrm{Sex}$-males $(\%)$ & $3(60 \%)$ & $2(40 \%)$ & $3(60 \%)$ \\
$\mathrm{MAP}(30 \mathrm{~min})$ & $8.9 \pm 0.4$ & $9.4 \pm 0.4$ & $8.9 \pm 0.2$ \\
$\mathrm{MAP}(24 \mathrm{~h})$ & $7.4 \pm 0.5$ & $7.4 \pm 0.5$ & $7.5 \pm 0.3$ \\
$\mathrm{ABG}-6 \mathrm{~h}$ & & & \\
$\mathrm{pH}$ & $7.35(0.03)$ & $7.35(0.05)$ & $7.43(0.03)$ \\
$\mathrm{PCO}_{2}(\mathrm{~mm} \mathrm{Hg})$ & $44(5)$ & $45(6)$ & $34(2)$ \\
$\mathrm{PaO}_{2}(\mathrm{~mm} \mathrm{Hg})$ & $74(5)$ & $79(9)$ & $369(6)$ \\
$\mathrm{BD}_{\mathrm{FiO}}$ & $-2.3(0.9)$ & $-2(1.2)$ & $-3.2(1.0)$ \\
$\mathrm{ABG}-12 \mathrm{~h}_{\mathrm{pH}}$ & $0.28(0.02)$ & $0.28(0.02)$ & 1.0 \\
$\mathrm{PCO}_{2}(\mathrm{~mm} \mathrm{Hg})$ & $7.33(0.04)$ & $7.28(0.04)$ & $7.37(0.03)$ \\
$\mathrm{PaO}_{2}(\mathrm{~mm} \mathrm{Hg})$ & $67(4)$ & $43(3)$ & $41(3)$ \\
$\mathrm{BD}_{\mathrm{FiO}}$ & $-3.3(2.3)$ & $-5.7(1.5)$ & $-3(1.0)$ \\
$\mathrm{ABG}-24 \mathrm{~h}_{\mathrm{pH}}$ & $0.26(0.02)$ & $0.25(0.02)$ & 1.0 \\
$\mathrm{PCO}_{2}(\mathrm{~mm} \mathrm{Hg})$ & $7.36(0.03)$ & $7.33(0.01)$ & $7.43(0.01)$ \\
$\mathrm{PaO}_{2}(\mathrm{~mm} \mathrm{Hg})$ & $45(2)$ & $45(2)$ & $37(1)$ \\
$\mathrm{BD}_{\mathrm{FiO}}$ & $56(6)$ & $67(3)$ & $472(4)$ \\
$\mathrm{Fals}_{2}$ & $0.6(1.0)$ & $0.1(0.1)$ & $0.6(0.5)$ \\
& $0.21(0.01)$ & $0.30(0.02)$ & 1.0 \\
\hline
\end{tabular}

Values are expressed as mean (SEM) in all the groups $(n=5)$. MAP, mean airway pressure.

Significant hypotension requiring neither volume nor metabolic acidosis requiring bicarbonate occurred in any of the lambs.

GSH/GSSG ratio. GSH levels were not significantly different among the groups over $24 \mathrm{~h}$ by mixed modeling. However, GSSG levels in the blood were significantly different among the groups with lower values in the RAR group and higher values in the OX24 group (Mixed modelling - group effect: $p=0.019$; time effect: $p=0.0001)$. The GSH/GSSG ratio was significantly different among the groups over time with higher ratios in RAR group and a lower ratio in OX24 group (Fig. 3A) (Mixed modeling— group effect: $p=0.0117$;

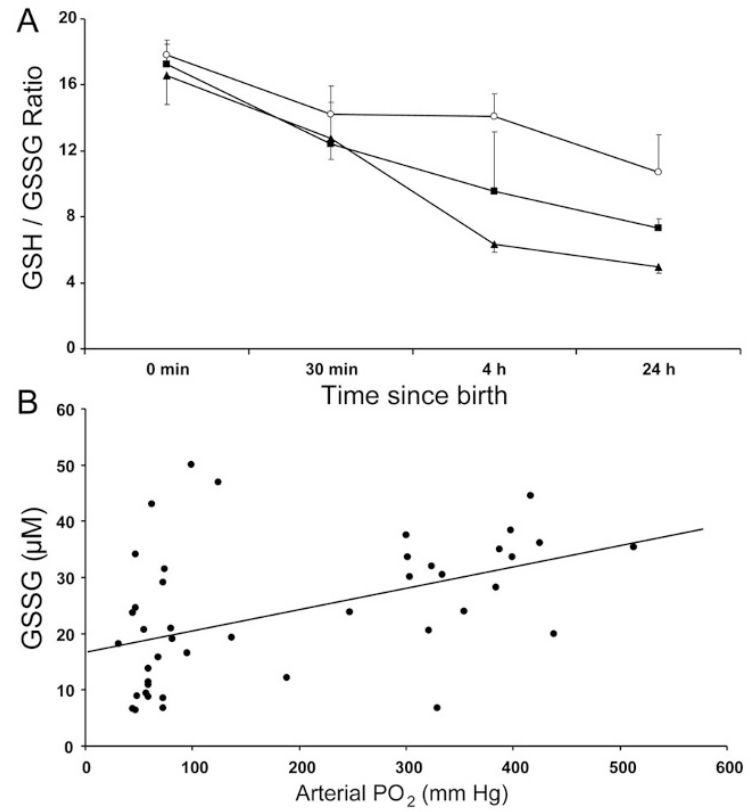

Figure 3. $A$, The figure represents GSH to GSSG ratio over time at all time points ( $0 \mathrm{~min}, 30 \mathrm{~min}, 4 \mathrm{~h}$, and $24 \mathrm{~h}$ ) in the three groups (RAR-open circles; OXR—closed squares; OX24_closed triangles). Values represent mean \pm SEM ( $n=5$ in each group). The ratio was significantly correlated among the groups with a higher ratio in the RAR group (Mixed modeling for GSH/GSSG ratio_-group effect: $p=0.0117$; time effect: $p<0.0001)$. $B$, Represents a linear regression plot of GSSG ( $y$ axis) $v s$ arterial $\mathrm{Po}_{2}(x$ axis) of all the post birth data points ( $30 \mathrm{~min}, 4 \mathrm{~h}$, and $24 \mathrm{~h}$ ) of all the groups combined. Plasma GSSG concentration was directly correlated with arterial $\mathrm{Po}_{2}$ independent of the groups $\left(R^{2}=0.12 ; p<0.01\right)$.

time effect: $p<0.0001)$. The GSSG values after birth (30 min, $4 \mathrm{~h}$, and $24 \mathrm{~h}$ ) were directly correlated to arterial $\mathrm{Po}_{2}$, independent of the group assignment by linear regression (Fig. $3 B$ ) $(p<0.01)$.

AOE activity in the lung and red blood cell lysate. The total SOD and GP activity in the lung was significantly higher in the OX24 group compared with the RAR group and the catalase activity was higher in the OX24 group compared with the RAR and OXR groups (Fig. 4). The AOE activities in the lung were not different between RAR and OXR groups. AOE activities directly correlated with alveolar $\mathrm{Po}_{2}$, independent of the group assignment by linear regression $\left(\mathrm{SOD}-\mathrm{R}^{2}: 0.678\right.$; $p=0.0001 ;$ Catalase $-\mathrm{R}^{2}: 0.271 ; p=0.046 ; \mathrm{GP}-\mathrm{R}^{2}: 0.385$; $p=0.0237)$. AOE activities in red blood cell (RBC) lysate were higher at $24 \mathrm{~h}$ compared with prebirth in the OX24 group (SOD and GP) (Fig. 5). SOD activity at $24 \mathrm{~h}$ in the OX24 group was higher compared with the RAR group. Similarly, GP activity in OX24 and OXR group at $24 \mathrm{~h}$ was higher compared with the RAR group.

LPO and MPO activities. Lung LPO, a marker of cell membrane damage was higher in OXR and OX24 groups compared with the RAR group (Fig. 6A). MPO activities in the lung and in the lavage supernatant were not different among the groups (Table 2). OX24 group had a significantly higher MPO activity in lavage cell suspension compared with the other groups (Table 2).

Cell counts, total protein, and lung wet to dry weight ratios. There was no difference in total cell count among the 

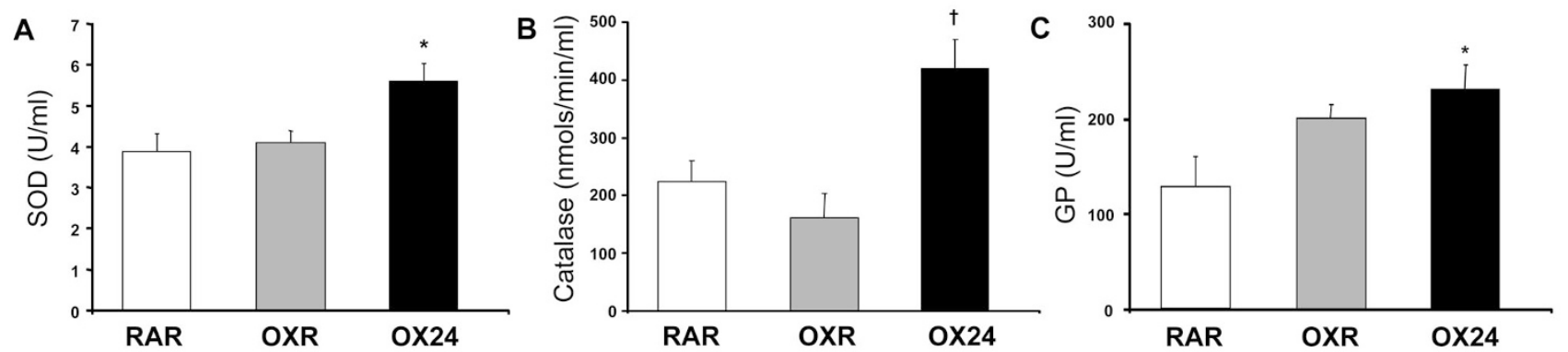

Figure 4. AOE activities in the lung after hyperoxia in term newborn lambs. SOD $(A)$, catalase $(B)$, and glutathione peroxidase $(C)$ activities in the lung in RAR (unfilled bars), OXR (gray bars), and OX24 (black bars) groups are shown. Values represent mean $\pm \operatorname{SEM}(n=5$ in each group). * $p<0.05 v s$ RAR; $\dagger p 0.05$ vs RAR and OXR group, ANOVA, Fisher posthoc test.
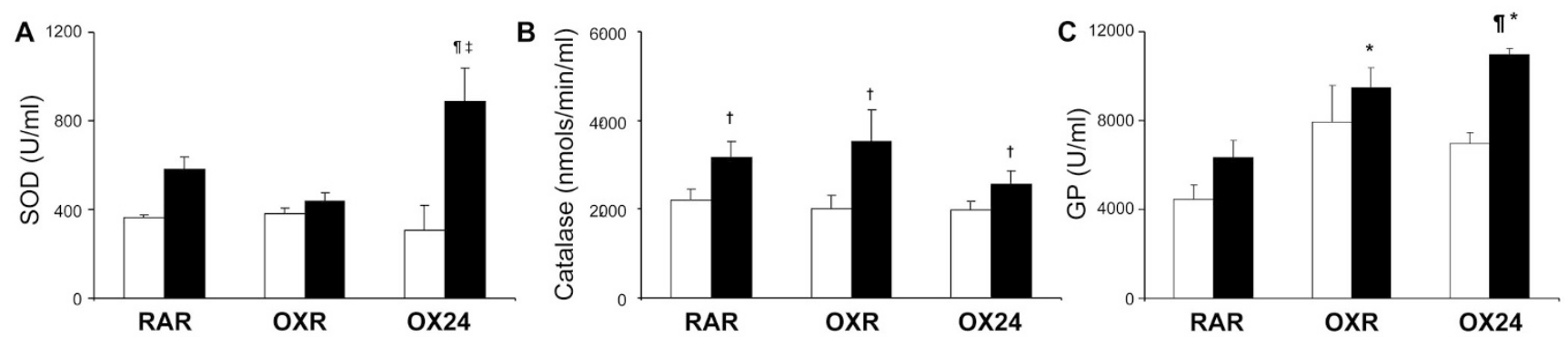

Figure 5. SOD $(A)$, catalase $(B)$, and glutathione peroxidase $(C)$ activities were measured in RBC lysate in the three groups. Prebirth (unfilled bars) and $24 \mathrm{~h}$ (black bars) values (mean \pm SEM) for all groups shown. $\mathbb{I} p<0.05 v s$ prebirth OX24; $\ddagger p<0.05 v s$ corresponding RAR and OXR groups; $\dagger p<0.05 v s$ corresponding prebirth; * $p<0.05$ vs corresponding RAR; ANOVA, Fisher posthoc test.

A

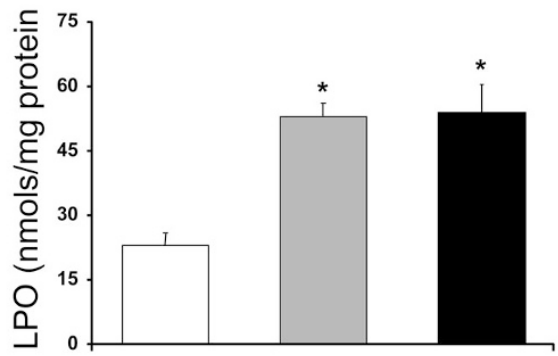

B

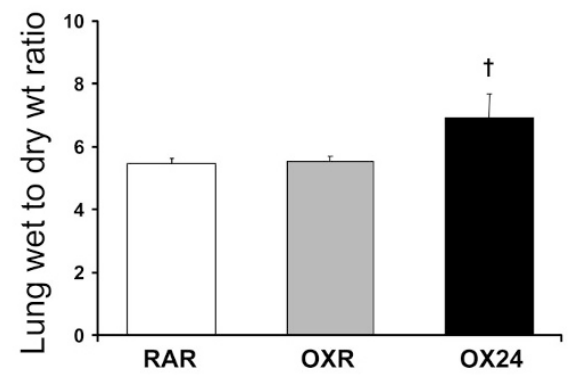

Figure 6. Lung injury markers in term lambs after hyperoxia. LPO $(A)$ and wet to dry weight ratios of the lung $(B)$ in RAR (unfilled bars), OXR (gray bars), and OX24 (black bars) groups are shown (mean \pm SEM). ${ }^{*} p<0.05$ vs RAR; $\dagger p<0.05$ vs RAR and OXR groups; ANOVA, Fisher posthoc test.

groups. OX24 group had significantly higher percent neutrophils on differential count (Table 3). There was no difference in the differential count between RAR and OXR groups. OX24 group also had higher protein content in lung lavage among the groups (Table 3). Lung wet to dry weight ratios were significantly higher in the OX24 group compared with the other groups (Fig. 6B).
Table 2. Myeloperoxidase activity in lung homogenate and in $L L$ in lambs exposed to different levels of oxygen

\begin{tabular}{llll}
\hline Groups & $\begin{array}{c}\text { Lung } \\
\text { homogenate }\end{array}$ & $\begin{array}{c}\text { Cell free LL } \\
\text { (supernatant) }\end{array}$ & $\begin{array}{c}\text { Lavage cell } \\
\text { pellet }\end{array}$ \\
\hline RAR & $48.8( \pm 9.4)$ & $46.8( \pm 9.1)$ & $232( \pm 13)$ \\
OXR & $44.9( \pm 14.6)$ & $55.5( \pm 11.5)$ & $222( \pm 5)$ \\
OX24 & $43.9( \pm 4.1)$ & $51.5( \pm 4.2)$ & $345( \pm 19)^{*}$ \\
\hline
\end{tabular}

LL MPO was measured in supernatant (cell free LL) and in cell pellet (LL cell suspension). MPO activity in lung homogenate is expressed as units/mg lung protein and as units/mg protein of LL.

Data are expressed as mean \pm SEM.

$* p<0.05$ vs RAR and OXR groups (ANOVA, Fisher posthoc test). LL, lung lavage.

\section{DISCUSSION}

Ventilation with room air in healthy term lambs neither resulted in metabolic acidosis nor significant changes in $\mathrm{pH}$ or $\mathrm{pCO}_{2}$ compared with $100 \% \mathrm{O}_{2}$ ventilation in the first $30 \mathrm{~min}$ of life. These results were similar to that reported previously in preterm lambs (12). The mean $\mathrm{FiO}_{2}$ was 0.21 to 0.25 in the RAR group and 0.24 to 0.30 in the OXR group beyond the first hour of life. These lambs were near term, required sedation and ventilated with an endotracheal tube in place which could explain this minimal oxygen requirement after birth. Oxidative stress is caused by an imbalance between the production of reactive oxygen species (ROS) and the biologic system's ability to detoxify these with the help of antioxidants. One of the molecules contributing to oxidative stress is a large decrease in the reducing capacity of cellular redox couples, such as glutathione (13). Reduced GSH is the one of the most important intracellular scavengers of free radicals and decreased GSH levels and increased GSSG levels may reflect 
Table 3. Total cell count, differential count, and total proteins in LL in newborn lambs exposed to varying levels of oxygen

\begin{tabular}{lccccc}
\hline Groups & Total WBC count $\left(\right.$ cells $\left./ \mathrm{mm}^{3}\right)$ & Neutrophils $(\%)$ & Macrophages $(\%)$ & Lymphocytes $(\%)$ & Total protein $(\mathrm{mg} / \mathrm{mL})$ \\
\hline RAR & $6,278( \pm 1,600)$ & 26 & 67 & 7 & $0.39( \pm 0.04)$ \\
OXR & $7,103( \pm 2,080)$ & 28 & 63 & 9 & $0.47( \pm 0.07)$ \\
OX24 & $9,576( \pm 1,340)$ & $43 *$ & 45 & 12 & $0.62( \pm 0.08)^{*}$ \\
\hline
\end{tabular}

Differential count is expressed as a percentage of the 100 cells seen. Total proteins expressed in $\mathrm{mg} / \mathrm{mL}$.

Data are expressed as mean \pm SEM.

$* p<0.05$ vs RAR and OXR group (Fisher posthoc test).

LL, lung lavage.

depletion of antioxidant reserve (13). The GSH/GSSG ratio decreases 15 - to 20-fold through the fetal-neonatal-adult transition in isolated hepatocytes in fetal and newborn rat liver and this was mainly due to an increase in GSSG (14). In our studies, GSSG increased and the glutathione redox ratio (GSH/GSSG) decreased over the first $24 \mathrm{~h}$ after birth irrespective of the grouping suggesting that transition to early neonatal life soon after birth is an oxidative stressful event. GSSG levels increased and the glutathione redox ratio decreased among the groupings based on oxygen exposure, suggesting the role of free radicals in the production of GSSG. GSSG was also correlated independently with arterial $\mathrm{PO}_{2}$ irrespective of the grouping indicating that hyperoxia contributed to oxidative stress in these newborn lambs. Oxygen at the time of birth may add to the physiologic oxidative stress soon after delivery $(6,15)$. In term human newborns, infants resuscitated with $100 \%$ oxygen exhibited higher GSH/GSSG ratios, even at 4 wk of age, suggesting prolonged oxidative stress compared with those resuscitated in room air (16).

AOE activities in the lung and RBC lysate give a measure of body's antioxidant activity defenses to a pro-oxidant situation resulting from production of free radicals. The increase in AOE activity in the OX24 group suggests that these lambs had an appropriate response to a pro-oxidant situation in the lung. This implies that in the immediate newborn period, the elevation of oxidative stress markers such as GSSG and LPO and AOE activities are related to amount and the duration of oxygen at least in the first $24 \mathrm{~h}$ of life. As the percent alveolar exposure to oxygen was higher $(100 \%)$ in the OX24 group, we speculate that the increase in the activity of the major AOEs in the lung may be related to the amount of alveolar oxygen exposure in term lambs. Susceptibility of the lung to oxidative injury depends largely on the ability to up-regulate ROS scavenging systems (17). SOD activity was significantly higher in the OX24 group in the lung and RBC lysate compared with the other two groups. Catalase in RBC lysate and $\mathrm{GP}$ in the tissues measured were not significant at $24 \mathrm{~h}$ and hence is of little clinical interest. The differential response in terms of AOE activities to hyperoxia may mean mechanisms underlying their regulation are also different. Our interpretation of the activity data are limited by the lack of mRNA and protein data, which could have given more information on mechanisms regulating AOE expression. In a time course similar to the maturation of the surfactant system, fetal lung AOE activity, specifically SOD, catalase and GP increases during the final 15 to $20 \%$ of intrauterine life (18). Term lambs can induce AOE activity at $24 \mathrm{~h}$ in the presence of maximal hyperoxia, suggesting the maturation of these pathways. Pre- term newborn lambs fail to up-regulate AOE activities at $24 \mathrm{~h}$ in contrast to term lambs (12). The response of AOE activity in the lung to the presence of hyperoxia varies in different species. Major AOE activities do not increase in response to hyperoxia in adult rabbits (19), whereas adult rats exposed to 80 to $85 \%$ oxygen demonstrate an increase in AOE activity (20). Similar to lambs in our experiments, newborn rabbits induce AOE activity in response to hyperoxia unlike premature rabbits (21). Extracellular AOEs are induced rapidly and in proportion to oxidative stress (22), relative to intracellular AOEs. Exposure to $>95 \%$ in adult rats and baboons for $48 \mathrm{~h}$ decreases MnSOD activity and this decrease was not due to failure to increase MnSOD mRNA, but rather due to impaired translational efficiency (23). Unfortunately, no clinical studies demonstrate that delivering antioxidants provide clear evidence of protection against lung injury. Despite relatively higher $\mathrm{PaO}_{2}$ than in any clinical circumstances in the OX24 group, oxidative stress markers such as GSSG and LPO are modestly elevated compared with other groups, suggesting that there are other signaling mechanisms that may be important within the cell in the presence of hyperoxia.

Maximal oxygen exposure in the presence of ventilation causes inflammation of the newborn lamb lung (high protein in lavage; high MPO in cell pellet). The methodology adopted for wet-dry weight ratio could have resulted in an incomplete drying process and hence the difficulty in interpreting lung edema. Even though we have shown that oxidative stress markers such as GSSG and LPO are elevated, it is not clear whether they are derived from lung cells under hyperoxia or from the phagocytes invading the lung as part of the inflammatory process induced by hyperoxia (24). In this model, inflammation from the effects of lung injury from ventilation as such is not possible to be differentiated from a pro-oxidant situation resulting from oxygen exposure, but ventilation was used in all the three groups. Hyperoxia has been shown to increase ventilator-induced lung injury, neutrophil influx into the lung and MIP-2 production (25). In rats exposed to high tidal volume ventilation, total lung neutrophil infiltration and MIP-2 in bronchoalveolar lavage were significantly elevated in room air or hyperoxia, but hyperoxia markedly augmented the migration of neutrophils into the alveoli (26). Lambs in all the groups were managed with similar ventilator strategies, but lambs exposed to $24 \mathrm{~h}$ of oxygen had a higher neutrophil response, suggesting hyperoxia in these lambs augmented neutrophil infiltration into the lung.

Numerous studies of hypoxia followed by reoxygenation have demonstrated the detrimental effects of resuscitation with $100 \%$ oxygen (27-29). Reoxygenation with $\geq 40$ to $60 \%$ 
oxygen causes increasing oxidative stress in newborn piglets after hypoxia (29). Resuscitation with $100 \%$ oxygen increases cerebral injury in newborn piglets (28) and cerebral inflammatory response in newborn sheep (27). Our study was a hyperoxygenation model without preceding hypoxia. A brief exposure to $100 \%$ oxygen induces oxidative stress and a more prolonged exposure to lung inflammation and oxidant lung injury even without a preceding hypoxic event. It would be interesting to note whether reoxygenation in the presence or absence of hypoxia would alter oxidative stress in the lung and other vital organs such as the brain, although that was not the intent of the current study. We agree that most term infants are not resuscitated in the absence of asphyxia, which is a major limitation of the study. The duration of "experimental resuscitation" was $30 \mathrm{~min}$, which would not be the case in a real time setting in the delivery room. However, before blenders were more widely available, $30 \mathrm{~min}$ would not be an unusual length of time for exposure to $100 \%$ oxygen.

In conclusion, in this model of varying exposure to supplemental oxygen in term lambs, OXR lambs had evidence of systemic oxidative stress over time and cell membrane damage at $24 \mathrm{~h}$ compared with the RAR group. Newborn lambs exposed to maximal oxygen had systemic oxidative stress, damage to cell membranes and higher activities of AOEs in response to a pro-oxidant situation and evidence of inflammation in the lung.

Acknowledgments. We thank Nasir Rashid, Margaret Brick, and Sharon Baumgartner for excellent technical assistance.

\section{REFERENCES}

1. Buonocore G, Perrone S, Longini M, Vezzosi P, Marzocchi B, Paffetti P, Bracci R 2002 Oxidative stress in preterm neonates at birth and on the seventh day of life. Pediatr Res 52:46-49

2. Buonocore G, Zani S, Perrone S, Caciotti B, Bracci R 1998 Intraerythrocyte nonprotein-bound iron and plasma malondialdehyde in the hypoxic newborn. Free Radic Biol Med 25:766-770

3. Kondo M, Itoh S, Isobe K, Kunikata T, Imai T, Onishi S 2000 Chemiluminescence because of the production of reactive oxygen species in the lungs of newborn piglets during resuscitation periods after asphyxiation load. Pediatr Res 47:524-527

4. Fellman V, Raivio KO 1997 Reperfusion injury as the mechanism of brain damage after perinatal asphyxia. Pediatr Res 41:599-606

5. American Heart Association; American Academy of Pediatrics 20062005 American Heart Association (AHA) guidelines for cardiopulmonary resuscitation (CPR) and emergency cardiovascular care (ECC) of pediatric and neonatal patients: neonatal resuscitation guidelines. Pediatrics 117:e1029-e1038

6. Vento M, Asensi M, Sastre J, Lloret A, Garcia-Sala F, Vina J 2003 Oxidative stress in asphyxiated term infants resuscitated with $100 \%$ oxygen. J Pediatr 142:240-246
7. Lakshminrusimha S, Russell JA, Steinhorn RH, Ryan RM, Gugino SF, Morin FC III, Swartz DD, Kumar VH 2006 Pulmonary arterial contractility in neonatal lambs increases with $100 \%$ oxygen resuscitation. Pediatr Res 59:137-141

8. Lakshminrusimha S, Russell JA, Steinhorn RH, Swartz DD, Ryan RM, Gugino SF, Wynn KA, Kumar VH, Mathew B, Kirmani K, Morin FC III 2007 Pulmonary hemodynamics in neonatal lambs resuscitated with $21 \%, 50 \%$, and $100 \%$ oxygen. Pediatr Res 62:313-318

9. Klein JA, Ackerman SL 2003 Oxidative stress, cell cycle, and neurodegeneration. J Clin Invest 111:785-793

10. Lalani S, Remmers JE, Green FH, Bukhari A, Ford GT, Hasan SU 2001 Effects of vagal denervation on cardiorespiratory and behavioral responses in the newborn lamb. J Appl Physiol 91:2301-2313

11. Lowry OH, Rosebrough NJ, Farr AL, Randall RJ 1951 Protein measurement with the Folin phenol reagent. J Biol Chem 193:265-275

12. Patel A, Lakshminrusimha S, Ryan RM, Swartz DD, Wang H, Wynn KA, Kumar VH 2009 Exposure to supplemental oxygen downregulates antioxidant enzymes and increases pulmonary arterial contractility in premature lambs. Neonatology 96:182192

13. Schafer FQ, Buettner GR 2001 Redox environment of the cell as viewed through the redox state of the glutathione disulfide/glutathione couple. Free Radic Biol Med 30:1191-1212

14. Pallardo FV, Sastre J, Asensi M, Rodrigo F, Estrela JM, Vina J 1991 Physiological changes in glutathione metabolism in foetal and newborn rat liver. Biochem $\mathrm{J}$ 274:891-893

15. Saugstad OD 2005 Room air resuscitation-two decades of neonatal research. Early Hum Dev 81:111-116

16. Vento M, Asensi M, Sastre J, Garcia-Sala F, Pallardo FV, Vina J 2001 Resuscitation with room air instead of $100 \%$ oxygen prevents oxidative stress in moderately asphyxiated term neonates. Pediatrics 107:642-647

17. Comhair SA, Erzurum SC 2002 Antioxidant responses to oxidant-mediated lung diseases. Am J Physiol Lung Cell Mol Physiol 283:L246-L255

18. Frank L, Sosenko IR 1987 Prenatal development of lung antioxidant enzymes in four species. J Pediatr 110:106-110

19. Baker RR, Holm BA, Panus PC, Matalon S 1989 Development of $\mathrm{O}_{2}$ tolerance in rabbits with no increase in antioxidant enzymes. J Appl Physiol 66:1679-1684

20. Vincent R, Chang LY, Slot JW, Crapo JD 1994 Quantitative immunocytochemical analysis of Mn SOD in alveolar type II cells of the hyperoxic rat. Am J Physiol 267:L475-L481

21. Frank L, Sosenko IR 1991 Failure of premature rabbits to increase antioxidant enzymes during hyperoxic exposure: increased susceptibility to pulmonary oxygen toxicity compared with term rabbits. Pediatr Res 29:292-296

22. Avissar N, Finkelstein JN, Horowitz S, Willey JC, Coy E, Frampton MW, Watkins RH, Khullar P, Xu YL, Cohen HJ 1996 Extracellular glutathione peroxidase in human lung epithelial lining fluid and in lung cells. Am J Physiol 270:L173-L182

23. Clerch LB, Massaro D, Berkovich A 1998 Molecular mechanisms of antioxidant enzyme expression in lung during exposure to and recovery from hyperoxia. Am J Physiol 274:L313-L319

24. Kinnula VL, Crapo JD, Raivio KO 1995 Generation and disposal of reactive oxygen metabolites in the lung. Lab Invest 73:3-19

25. Li LF, Liao SK, Ko YS, Lee CH, Quinn DA 2007 Hyperoxia increases ventilatorinduced lung injury via mitogen-activated protein kinases: a prospective, controlled animal experiment. Crit Care 11:R25

26. Quinn DA, Moufarrej RK, Volokhov A, Hales CA 2002 Interactions of lung stretch, hyperoxia, and MIP-2 production in ventilator-induced lung injury. J Appl Physiol 93:517-525

27. Markus T, Hansson S, Amer-Wahlin I, Hellstrom-Westas L, Saugstad OD, Ley D 2007 Cerebral inflammatory response after fetal asphyxia and hyperoxic resuscitation in newborn sheep. Pediatr Res 62:71-77

28. Munkeby BH, Borke WB, Bjornland K, Sikkeland LI, Borge GI, Halvorsen B, Saugstad OD 2004 Resuscitation with 100\% O2 increases cerebral injury in hypoxemic piglets. Pediatr Res 56:783-790

29. Solberg R, Andresen JH, Escrig R, Vento M, Saugstad OD 2007 Resuscitation of hypoxic newborn piglets with oxygen induces a dose-dependent increase in markers of oxidation. Pediatr Res 62:559-563 